\title{
Hardness Evaluation on SS 316L Joined with Gas Tungsten Arc Welding Under Constant Heat Treatment
}

\author{
Duwi Leksono Edy*, Imam Sudjono \\ Mechanical Engineering Department, Universitas Negeri Malang \\ Jl. Semarang 5, Malang, East Java, Indonesia 65145 \\ *Corresponding author: duwi.leksono.ft@um.ac.id
}

\begin{abstract}
The purpose of this study is to show the hardness of the GTAW welding results on SS 316L metal with surface heating during the welding process. Observations in this study used SS 316L material with heat temperature regulation on the metal surface of the welding process using heating variations of $100{ }^{\circ} \mathrm{C}, 120$ ${ }^{\circ} \mathrm{C}$ and $140{ }^{\circ} \mathrm{C}$. The welding process of SS $316 \mathrm{~L}$ material used a welding joint model uses single V-type welding joint with an angle of $60^{\circ}$, a spacing of $2 \mathrm{~mm}$, a root surface of $1 \mathrm{~mm}$ and a thickness of $5 \mathrm{~mm}$. Vickers hardness test was conducted to evaluate the hardness of samples. The results indicate that all specimens show a difference in the level of violence comparing with the values of the average level of hardness in each weld specimen. Specimens with the welding process heating temperature $100{ }^{\circ} \mathrm{C}$ have an average hardness value of $115.6 \mathrm{HVN}$. In contrast, samples with heating $120^{\circ} \mathrm{C}$ have increased by having an average hardness value of 131.0 HVN. In comparison, heating specimens with heating surfaces of welding $140{ }^{\circ} \mathrm{C}$ have an increase in hardness values with an average of $171.5 \mathrm{HVN}$.
\end{abstract}

Copyright @ 2020 . Journal of Mechanical Engineering Science and Technology

All rights reserved

Keywords: Gas Tungsten Arc Welding (GTAW), heat treatment, SS 316L steel

\section{Introduction}

SS 316L material is stainless steel which has been widely used in the world of oil, gas and manufacturing industries. In the welding process of SS316L material, the welding heat melts the end surface of the welded parent metal which blends with the fused metal fills in the weld area and its surroundings and gives the effect of changing the mechanical and geometrical properties of the weld metal [1]. Factors that affect the mechanical properties of welds are affected by the cooling rate that influenced by several factors, namely plate thickness, welding conditions, preheat, heat input and the environment [2]. Heat input is one parameter that contributes to distortion and residual stress [4][6].

In previous studies, the process of cooling treatment after welding to obtain the mechanical properties of metals [6]-[10]. The more welding layers increase, the higher the distortion. On thin plates, distortion often occurs, resulting in undesirable dimensions of dimension changes. But on thick plates with a broad cross-section, distortion is not visible, but the formed residual stress is considerable if a measurement is made. Changes in the geometry of the welds occur due to local heating with welding heat sources where the temperature distribution is uneven and changing, as well as changes in welding speed [3]. The heating process on the outside of the welding surface also increases welding strength [12]. 
Different heating processes use plasma for preheating in aluminium alloy welding [13], while other studies conduct the design heating using gas heaters for preheating in carbon steel welding [14][15]. The excessive heating temperature or less heating temperature affects the welding results, and this proof will be evaluated through the heating process during the welding process on SS $316 \mathrm{~L}$ metal. The purpose is to show the hardness of the metal after the welding process with Tungsten Gas Arc Welding under Constant Heat Treatment.

\section{Material and Methods}

This study used material of SS 316L, and heat temperature treatment on the metal surface of the welding process applied the heating variations of $100^{\circ} \mathrm{C}, 120^{\circ} \mathrm{C}$, and $140^{\circ} \mathrm{C}$. The welding process of SS $316 \mathrm{~L}$ material with a welding joint model used single V-type welding joint with an angle of $60^{\circ}$ (Figure 1), root spacing $2 \mathrm{~mm}$, root surface $1 \mathrm{~mm}$ at a thickness of $5 \mathrm{~mm}$. The work of making specimens which include cutting material, making the seam is done by cold working. It was intended to change the mechanical properties of SS 316L material due to the influence of heat that arises when the working process occurs. Welding was carried out at the welding lab of Malang State University using ESAB Asia/Pacific low product hydrogen electrodes for small alloy steel types, namely basic OK 74.78. The electrodes used in welding high strength steels and also for low-temperature construction.

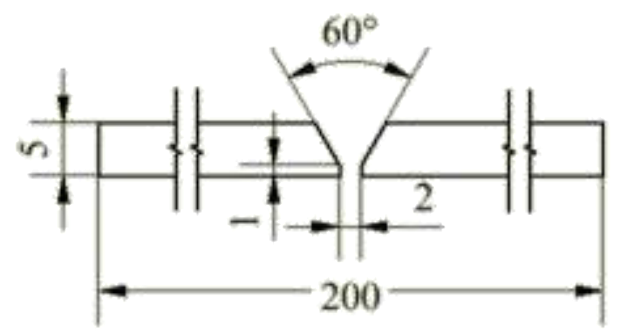

Fig 1. Size of the weld seam

The chemical composition of SS 316L material in this study is shown in Table 1.

Table 1. Chemical composition of 316 stainless steel.

\begin{tabular}{lr}
\hline Elements & Weight Percentage \\
\hline Carbon & 0.08 \\
Manganese & 2.00 \\
Sulphur & 0.030 \\
Silicon & 0.75 \\
Nitrogen & 0.10 \\
Phosphorus & 0.045 \\
Chromium & $16.0-18.0$ \\
Nitrogen & 0.10 \\
Nickel & $10.0-14.0$ \\
Molybdenum & $2.0-3.0$ \\
\hline
\end{tabular}

The material specifications were 316 Austenitic stainless steel with a thickness of 3 $\mathrm{mm}$, length of $100 \mathrm{~mm}$ and the number of samples were 27 . 


\section{Results and Discussions}

The welding area is observed as eleven as the welding process by giving a heating process to the metal surface during the welding process. The welding area is generally divided into three regions that experience differences between base metal, weld metal, Heat Affected Zone (HAZ) [16]. In detail, the discussion of the hardness of welds through the Vickers hardness test in the weld area will be discussed.

\section{Heating Temperature $100^{\circ} \mathrm{C}$.}

The final results of the welding process by heating the metal surface reaches a temperature of $100{ }^{\circ} \mathrm{C}$, macrostructural of welding obtained, as shown in Figure 2.

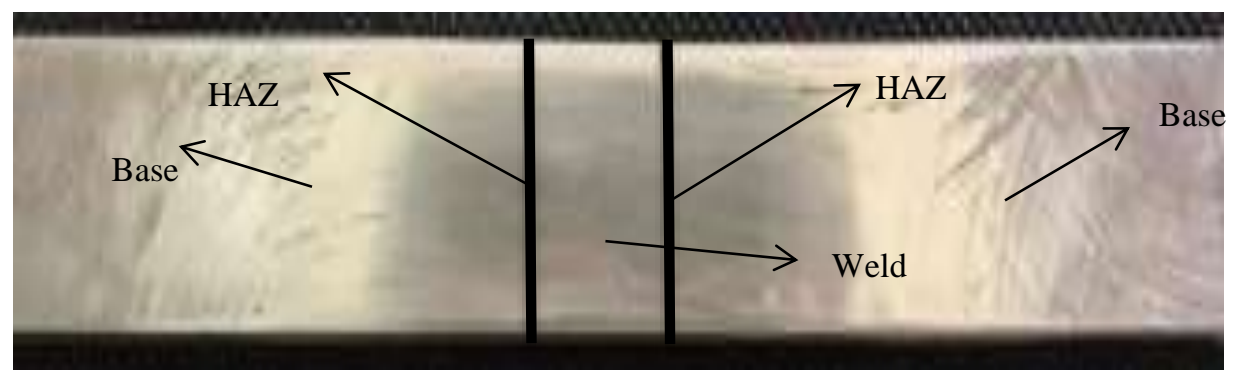

Fig 2. GTAW welding results with a constant temperature of $100{ }^{\circ} \mathrm{C}$

The macrostructure shows the results of welding with surface heating has a hardness level with an average value of 115.6 VHN, as shown in Table 2.

Table 2. Vickers hardness test results on GTAW welding results with a constant the temperature of $100{ }^{\circ} \mathrm{C}$.

\begin{tabular}{lrr}
\hline Heating Temperature & Test Point & Hardness Test (VHN) \\
\hline $100^{\circ} \mathrm{C}$ & 1 & 112.5 \\
& 2 & 118.6 \\
& 3 & 104.6 \\
& 4 & 116.8 \\
& 5 & 114.4 \\
& 6 & 122.3 \\
& 7 & 120.8 \\
\hline & & 115.6 \\
\hline
\end{tabular}

\section{Heating Temperature $120^{\circ} \mathrm{C}$.}

Metal surface heating is carried out by the next GTAW welding process with a heating temperature of $120{ }^{\circ} \mathrm{C}$ in order to compare and see the maximum results from this test. From the results of surface heating in this treatment, we get a macrostructure image, as shown in Figure 3.

The results of surface heating with a temperature of $120^{\circ} \mathrm{C}$ shows different macrostructure. The Vickers hardness test indicates an average value of hardness level of 131.0 VHN (Table 3). The level of violence at each point experiences an insignificant difference. 


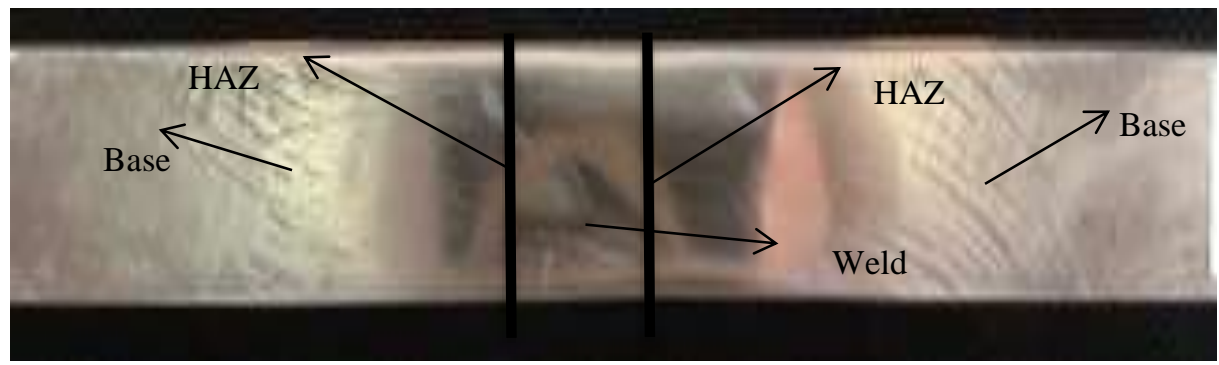

Fig 3. GTAW welding results with a constant temperature of $120^{\circ} \mathrm{C}$

Table 3. Vickers hardness test results on GTAW welding results with a constant temperature of $120^{\circ} \mathrm{C}$.

\begin{tabular}{lrr}
\hline Heating temperature & Test point & Hardness test (VHN) \\
\hline $120^{\circ} \mathrm{C}$ & 1 & 132.6 \\
& 2 & 137.9 \\
& 3 & 129.6 \\
& 4 & 131.7 \\
& 5 & 134.7 \\
& 6 & 130.3 \\
& 7 & 120.8 \\
\hline & & 131.0 \\
\hline
\end{tabular}

\section{Heating Temperature $140{ }^{\circ} \mathrm{C}$.}

Consider to the latter to produce the right level of hardness; heating was done by adding a temperature of $140{ }^{\circ} \mathrm{C}$. The result of the macro welding structure is shown in Figure 4.

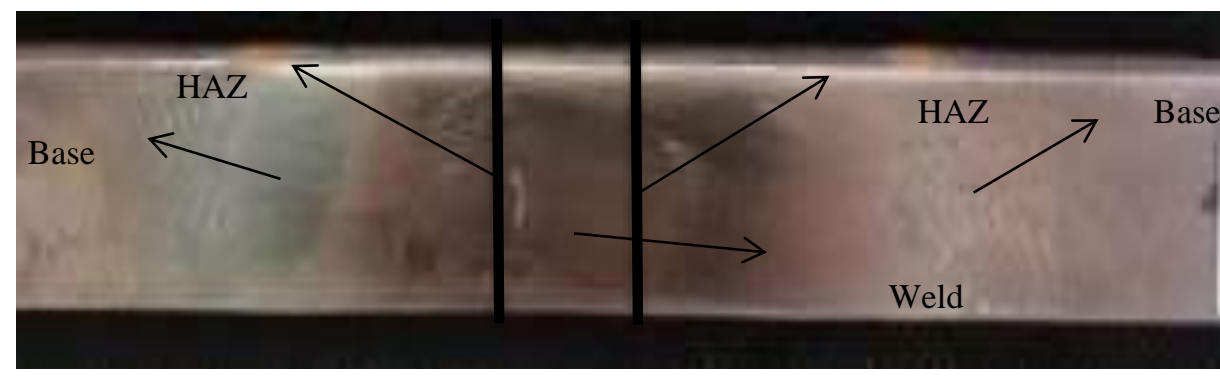

Fig 4. GTAW welding results with a constant temperature of $140^{\circ} \mathrm{C}$

While comparing the final results to produce a more effective level of violence, the hardness test with a surface heating of $140{ }^{\circ} \mathrm{C}$ obtained an average value of $171.5 \mathrm{VHN}$. Table 4 shows the level of surface hardness also does not experience a significant difference. This case is due to the amount of the current (ampere), the type of electrode and the same speed 
Table 4. Vickers hardness test results on GTAW welding results with a constant the temperature of $140{ }^{\circ} \mathrm{C}$.

\begin{tabular}{lrr}
\hline Heating Temperature & Test Point & Hardness Test (VHN) \\
\hline $140^{\circ} \mathrm{C}$ & 1 & 165.8 \\
& 2 & 175.5 \\
& 3 & 170.3 \\
& 4 & 167.4 \\
& 5 & 174.6 \\
& 6 & 178.3 \\
& 7 & 168.8 \\
\hline Average & & 171.5
\end{tabular}

\section{Hardness Test Data Analysis}

From the results of the hardness test of the welding process to the three specimens, the ANOVA test will be conducted to see an efficient comparison of results. This step was taken to see the contribution of differences in heating on the SS 316L metal surface by welding GTAW. The results of the Vickers hardness test for each specimen described through the ANOVA analysis results are shown in Table 5.

Table 5. Homogeneity test of variances hardness test results

\begin{tabular}{lccc}
\hline Levene Statistic & df1 & df2 & Sig. \\
\hline .137 & 2 & 18 & .873 \\
\hline
\end{tabular}

Table 6. ANOVA analysis of hardness test results

\begin{tabular}{lrrrrr}
\hline & Sum of Squares & df & Mean Square & F & Sig. \\
\hline Between Groups & 11666.000 & 2 & 5833.000 & 201.690 & .000 \\
Within Groups & 520.571 & 18 & 28.921 & & \\
Total & 12186.571 & 20 & & \\
\hline
\end{tabular}

The Anova test (Table 6) is used to determine the parameters of how much heating effect on the metal surface by GTAW welding. The variations in the hardness level at each point show that the level of hardness of the metal is significant differences. The Anova analysis shows that hardness level will have a different peak temperature with different cooling acceleration due to heating of the given metal surface. A right procedure was obtained from the results of this study, which can be applied in the testing process.

\section{Conclusions}

It can be concluded that the welding process of SS 316L material with heating temperature $100{ }^{\circ} \mathrm{C}, 120{ }^{\circ} \mathrm{C}, 140{ }^{\circ} \mathrm{C}$ results in an average hardness value of $115.6 \mathrm{HVN}$, 131.0 $\mathrm{HVN}$, and 171.5 HVN, respectively. ANOVA analysis indicates that the variations in the hardness level at specimens are significant differences. By providing heat to the 
metal surface during the welding process will affect the price of cooling on the metal surface.

\section{Acknowledgement}

Thank's to all members of this study for their valuable technical support for this research. My special thanks also go to the Faculty of Engineering, the State University of Malang, which provides research opportunities through the 2020 faculty grants program.

\section{References}

[1] H.Y. Huang, S.W. Shyu, Tseng, K.H. \& C.P. Chou, "Study of the process parameters on austenitic stainless steel by TIG-flux welding", Journal of Material Science and Technology, vol. 22 (8), pp. 367-374, 2008.

[2] J.C. Lippold, J.K. Damian, Welding metallurgy and weldability of stainless steel. Wiley-Interscience Publication. 2005.

[3] P. Burgardt, \& C.R. Heiple, "Interaction between impurities and welding variables in determining GTA weld shape", Welding Journal, vol. 65 (6), pp. 150-155, 1986.

[4] J.C.F. Jorge, L.F.G. Souza, P.M.C.L. Pacheco, R. D. Vieira, P.P. Kenedi, A.M.F. dos Santos Filho, O.R. dos Santos Filho, I.S. Bott, L.C.S. da Costa, "Desenvolvimento de procedimento de reparo por soldagem de amarras de aço para ancoragem de plataformas de petróleo". In Proceedings of the 27th Brazilian Welding Congress XXVII CONSOLDA, Paper 40. São Paulo, Brazil, 2001.

[5] J.C.F. Jorge, L.F.G. Souza, O.R. Santos Filho, A.M.F. Santos Filho, and I.S. Bott "Influência da composição química e tratamento térmico pós-soldagem nas propriedades mecânicas e microestruturais de metais de solda de alta resistência". In Proceedings of 33rd Brazilian Welding Congress - XXXIII CONSOLDA. Caxias do Sul, Brazil, 2007.

[6] J.C.F. Jorge, L.F.G. Souza, P.M.C.L. Pacheco, A.M.F.S. Filho, O.R. Santos Filho, J.L.C. Diniz and I.S. Bott. "Evaluation of the mechanical properties of welded links of high strength steel mooring chains after fatigue testing". In Proceedings of the 2 nd Latin American Welding Congress. São Paulo, Brazil, 2008.

[7] J.C.F. Jorge, S.M. Faragasso, L.F.G. Souza and I.S Bot. "Efeito do tratamento térmico pós-soldagem nas propriedades mecânicas e microestruturais de metal de solda de aço de extra alta resistência para utilização em equipamentos de ancoragem”. Soldagem \& Inspeção, vol. 18 (2), pp. 137-148, 2013.

[8] A.J.M. Gomes, J.C.F. Jorge, L.F.G. Souza, I.S Bott.“Estudo comparativo de metais de solda de aços de extra alta resistência para utilização em componentes de linhas de ancoragem de plataformas de petróleo". In Proceedings of the 67th ABM International Congress. Rio de Janeiro, Brazil, 2012.

[9] A.J.M. Gomes, J.C.F. Jorge, L.F.G. Souza, I.S Bott. "Influence of chemical composition and post welding heat treatment on the microstructure and mechanical properties of high strength steel weld metals". Materials Science Forum, vol. 758, pp. 21-32, 2013.

[10] P.M.C.L. Pacheco, P.P. Kenedi, J.C.F. Jorge, E.M.D. Coelho and G.S. Matoso. 
"Modeling the residual life of recovered schackles". In Proceedings of 20th International Conference on Offshore Mechanics and Artic Engineering - OMAE 2001. Rio de Janeiro, Brazil, 2001.

[11] J.A. Sumam, J.C.F. Jorge, L.F.G. Souza, and I.S. Bott. "Efeito de tratamentos térmicos pós-soldagem nas propriedades de aço fundido de elevada resistência para sistemas de ancoragem de plataformas marítimas". Soldagem \& Inspeção, vol 9 (4), pp. 205-212, 2004.

[12] Kandasamy, M Manzoor Hussain, and S. Rajesham, "Experimental investigation on the influence of external heating on the mechanical and metallurgical properties in friction stir welding of 7075 alloys", International Conference on Design and Advances in Mechanical Engineering, pp 266-271, 2011.

[13] D.K. Yaduwanshi, S. Bag, and S. Pal, "Effect of Preheating in Hybrid Friction Stir Welding of Aluminum Alloy," Journal of Materials Engineering and Performance, vol.29, 2014.

[14] H. Lotfi, and S. Nourouzi, "Predictions of the optimized friction stir welding process parameters for joining AA7075-T6 aluminum alloy using preheating system," International Journal of Advance Manufacturing Technology, vol.28, 2014.

[15] Y.F. Sun, J.M. Shen, Y. Morisada, and H. Fujii, "Spot friction stir welding of low carbon steel plates preheated by high frequency induction," Materials and Design, vol. 54, pp. 450-457, 2014.

[16] N. Rajamanickam, and V. Blusamy, "Effects of process parameters on mechanical properties of friction stir welds using design of experiments," Indian Journal of Engineering \& Materials Sciences, vol.15, pp. 293-299, 2008. 